\title{
EXPERIMENTAL ANALYSIS OF THE INFLUENCE OF CONCRETE CURING ON THE DEVELOPMENT OF ITS ELASTIC MODULUS OVER TIME
}

\author{
EKSPERIMENTALNA ANALIZA VPLIVA UTRJEVANJA BETONA \\ NA RAZVOJ MODULA ELASTIČNOSTI V DALJŠEM ČASOVNEM \\ OBDOBJU
}

\author{
Dalibor Kocáb, Monika Králíková, Petr Cikrle, Petr Misák, \\ Barbara Kucharczyková \\ Brno University of Technology, Faculty of Civil Engineering, Veveří 95, 60200 Brno, Czech Republic \\ kralikova.m@fce.vutbr.cz \\ Prejem rokopisa - received: 2016-08-08; sprejem za objavo - accepted for publication: 2016-12-13
}

doi: $10.17222 / \mathrm{mit} .2016 .248$

\begin{abstract}
The modulus of elasticity is one of the most important properties of concrete, especially during structural analyses of buildings. It is, among others, an important parameter in the calculation of the concrete-element deflection or during the design of pre- or post-tensioned structures. The modulus of elasticity is not a specific number. It is a property with a high variability of the final values, which depend on the concrete composition (together with other factors). Some of the significant factors, which influence the final value of the elastic modulus of concrete, are also the means and quality of its curing, especially at the early stage of its setting and hardening. Apart from maintaining the temperature within the correct limits, it is important to focus on the moisture content of concrete while it is being cured. The purpose of the experiment described herein was to determine the development of the dynamic as well as static modulus of elasticity for structural concrete while using different curing methods. The experiment used four series of beam specimens with nominal dimensions of $100 \times 100 \times 400 \mathrm{~mm}$ made from air-entrained and non-air-entrained concretes of the C $30 / 37$ strength class. A half of the specimens in each series aged in laboratory conditions and the other half was stored under water. Based on the evaluation of the experimental measurements, it can be said that the manner of storage has a significant influence on the development and final values of the static and dynamic modulus of elasticity.

Keywords: concrete, curing, modulus of elasticity, compressive strength

Ena od najpomembnejših lastnosti betona je modul elastičnosti. Njegovo poznavanje je še posebej pomembno za strukturno analizo stavb. To je, med drugim, pomemben parameter pri izračunu deformacij betonskih elementov pred ali med oblikovanjem prednapetih struktur. Modul elastičnosti ni specifična številka; je lastnost z zelo različnimi končnimi vrednostmi, ki so odvisne od sestave betona (skupaj z drugimi dejavniki). Pogoji njegovega utrjevanja so zelo pomembni. Vplivajo na končno velikost elastičnega modula betona, zlasti v zgodnji (začetni) fazi utrjevanja. Razen ohranjanja temperature v pravilnih mejah, se je pomembno osredotočiti na vsebnost vlage v betonu, medtem, ko se le-ta utrjuje. Namen opisanega preizkusa je bil določiti tako razvoj dinamičnega kot tudi statičnega modula elastičnosti konstrukcijskega betona, $\mathrm{z}$ uporabo različnih metod utrjevanja. V preizkusu so bile uporabljene štiri serije preizkušancev v obliki nosilcev z nazivnimi dimenzijami $100 \mathrm{~mm} \times 100 \mathrm{~mm} \times 400$ $\mathrm{mm}$, izdelanih iz zračno tretiranih in netretiranih betonov iz trdnostnega razreda C $30 / 37\left(\mathrm{~N} / \mathrm{mm}^{2}\right)$. Polovica vzorcev v vsaki seriji je bila starana $v$ laboratorijskih pogojih, druga polovica pa je bila shranjena $v$ vodi. Na podlagi vrednotenja eksperimentalnih meritev, lahko rečemo, da način shranjevanja pomembno vpliva na razvoj in končne vrednosti statičnega in dinamičnega modula elastičnosti.

Ključne besede: beton, utjevanje, modul elastičnosti, tlačna trdnost
\end{abstract}

\section{INTRODUCTION}

The recent development in civil engineering has been the cause of concrete being subject to far stricter requirements than several decades ago., ${ }^{1,2}$ The compressive strength is no longer the single governing parameter in the design of concrete structures. Attention is paid to other properties, which affect mainly the deformation of the structural element in question and the knowledge of their real values is more frequently sought and required. Next to the very frequently discussed durability, ${ }^{3,4}$ these properties include mainly deformation properties, among which the most important is considered to be the modulus of elasticity. ${ }^{5-8}$ The modulus of elasticity is one of the most important physical properties, which characterise a material. This applies to concrete as well, especially when it comes to the structural calculations of the structures sensitive to deformation. , $7,9^{2}$

The development of new kinds of concrete, such as self-compacting concrete (SCC), high-strength concrete (HSC), ultra-high performance concrete (UHPC) or freshly compressed concrete (FCC) pushes the boundaries of their material characteristics and properties and thus also their usability in civil engineering. ${ }^{10-13}$ The compressive strength can be significantly improved with a simple addition of state-of-the-art admixtures and additives; however, an improvement in the modulus of elasticity is much harder to guarantee. This fact is visible in a very interesting comparison of the relationship between the compressive strength and the modulus of elasticity as proposed by EC2 ${ }^{14}$ and the relationships described in other sources. ${ }^{2}$ 
The concrete modulus of elasticity is not a constant ${ }^{15-18}$; on the contrary, it is a property with a result variability, which depends mainly on the composition of the concrete in question. The resulting value of the elastic modulus is influenced mainly by the type, fraction and amount of coarse aggregate, while a decisive factor is often the ratio of the coarse aggregate to the total volume of cement paste. The value is also affected by the type of admixtures, especially the air-entraining ones, their content or the resulting w/c ratio. ${ }^{5,9,16,19}$ The curing of concrete, especially during the setting and early hardening, is another significant factor. Apart from maintaining the correct thermal conditions during the concrete manufacture, placement and curing, it is also necessary to pay attention to the moisture conditions after the concrete has been placed and while it ages. ${ }^{20,21}$ Especially during placements at high ambient temperatures, it is necessary to cure the concrete carefully for the first few hours or even days in order to prevent rapid water evaporation from the concrete's surface, which can result in the formation of microcracks not only on the surface but anywhere inside it as well.

A lack of water, especially at an early age, has a critical impact on the overall advancement of hydration, which is further reflected in rapid shrinkage; this is typically the first cause of the microcracks forming inside of a concrete element's structure. ${ }^{22,23}$ These microcracks further influence the development of physico-mechanical properties of the concrete throughout its ageing and can greatly affect the durability of the whole concrete structure. It was demonstrated that curing time (not only the curing method) also substantially influences the resulting values of the concrete's material properties. ${ }^{24,25}$ The composition, the water content, the curing method and the time are interlinked throughout the whole duration of the concrete ageing and can be considered as influential factors, which affect the final value of its modulus of elasticity. ${ }^{21}$

Another aspect, which is reflected in the final value of the modulus of elasticity, is the choice of the test method for its determination. The methods commonly used in civil engineering are the dynamic ones, e.g., the ultrasonic-pulse velocity test, resonance or impact-echo method $^{6,26}$, and the static methods, such as the compressive-strength test, flexural-strength test or modified-compact-tension test (MCT). ${ }^{15,27-29}$ The result of the dynamic tests is the initial tangent modulus of elasticity ${ }^{16}$ and it reaches higher values than the elastic modulus obtained with the static tests. The fact of the matter is that during static tests, the loading and unloading reduce the subsequent creep, which causes a change in the steepness of the stress-strain curve. The static modulus of elasticity is thus often called the secant and its values are lower. ${ }^{16}$ The resulting values of the modulus of elasticity obtained by means of each of the dynamic methods are not identical and this fact applies to the values obtained with the static methods as well. Apart from the choice of method, the final result is also influenced by the shape and slenderness ratio of the specimen used (beam ${ }^{9}$ vs. cylinder ${ }^{15}$ ) or its size. ${ }^{6}$ The issue of the modulus of elasticity of concrete is, therefore, still open and topical.

One of the key factors described above is the method of curing after concrete has been placed in a formwork. Not only the method and quality of curing have an effect, the curing time does as well. The longer and more intensively concrete is cured, the higher is the chance of improvement in its properties, including the modulus of elasticity. For this reason, the authors of this paper focused on a detailed analysis of the influences the method and time of concrete curing have on its modulus of elasticity.

\section{EXPERIMENTAL PART}

The purpose of the experiment described herein was to determine the development of the elastic modulus of concrete (this particular one was designed for the construction of bridges) cured under different conditions. Half of the specimens were immersed in water and the other half was stored in standard laboratory conditions with no direct contact with liquid water. The goal was to analyse the influence of the method and the time of curing on the development of the concrete's elastic modulus and its final value. Apart from the static modulus of elasticity, the concrete was tested for the dynamic modulus as well. Two non-destructive methods were used for this purpose.

\subsection{Test method}

The experiment used the ultrasonic-pulse velocity test and the resonance method for the determination of the dynamic modulus of elasticity. The static modulus of elasticity was determined by means of subjecting the specimens to a cyclic compressive stress.

\subsubsection{Ultrasonic-pulse velocity test}

The principle of the ultrasonic-pulse velocity test is the repeated releasing of ultrasonic impulses into the sample and measuring the time $\mathrm{T}$ required for them to travel through, which is then used for determining the velocity of ultrasonic-wave propagation $v_{\mathrm{L}}$ through the concrete. This velocity is, to some extent, a matter of consensus as the real distance the ultrasonic-pulse travels is not precisely known (i.e., the velocity is calculated with the measured time and the length of a specimen). In the end, the dynamic modulus of elasticity is calculated using Equation (1):

$$
E_{\mathrm{cu}}=D \cdot v_{\mathrm{L}}^{2} \cdot \frac{1}{k^{2}} \cdot 10^{-6}
$$

where $E_{\text {cu }}$ is the dynamic modulus of elasticity in MPa, $D$ is the material's bulk density in $\mathrm{kg} / \mathrm{m}^{3}, v_{\mathrm{L}}$ is the ultrasonic-pulse velocity in $\mathrm{m} / \mathrm{s}$ and $k$ is the dimensionality coefficient. 


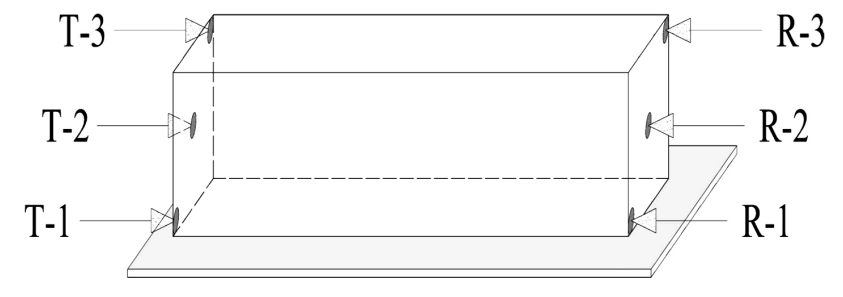

Figure 1: Diagram showing the arrangement for the test determining the time of the ultrasonic-wave passage through a specimen; the arrows indicate the positions, at which the measurement was performed; $\mathrm{R}$ is the receiver, $\mathrm{T}$ is the transmitter

The dimensionality coefficient $k$ equals 1 for a onedimensional environment and in the cases of two- and three-dimensional environments, it depends on the value of Poisson's ratio $\mu$, which can be determined by means of the resonance method (as was done in the experiment described here).

The velocity of the ultrasonic-wave propagation was measured using $82 \mathrm{kHz}$ transducers. The time, for which the ultrasonic pulse travelled through each specimen was measured longitudinally in three positions, as illustrated by Figure 1. The ultrasonic-wave velocity was calculated for each position and the average of the results was used as the velocity $v_{\mathrm{L}}$ in the calculation of the elastic modulus according to Equation (1). High-plasticity modelling clay was used to ensure a sufficient acoustic coupling between the transducers and the specimens. Prior to the measurement of each specimen, the testing instrument was calibrated using a calibration rod.

\subsubsection{Resonance method}

Every solid object vibrates upon a mechanical impulse, which can manifest itself in several ways. The dynamic material properties of a body with regular geometry are evaluated using the natural frequencies of longitudinal vibration $f_{\mathrm{L}}$, flexural vibration $f_{\mathrm{f}}$ and torsional vibration $f_{\mathrm{t}}$. Using the measured natural frequencies, the dynamic moduli of elasticity $E_{\mathrm{crL}}$ of the material under tension and compression (longitudinal vibration) can be calculated according to Equation (2):

$$
E_{\mathrm{crL}}=4 L^{2} \cdot f_{\mathrm{L}}^{2} \cdot D
$$

where $E_{\mathrm{crL}}$ is the dynamic compressive modulus of elasticity in $\mathrm{MPa}, L$ is the specimen length in $\mathrm{m}, f_{\mathrm{L}}$ is the natural frequency of longitudinal vibration in $\mathrm{kHz}$ and $D$ is the material's bulk density in $\mathrm{kg} / \mathrm{m}^{3}$, while $E_{\mathrm{crf}}$ (from flexural vibration) is obtained using Equation (3):

$$
E_{\mathrm{crf}}=0.0789 \cdot c_{1} \cdot L^{4} \cdot f_{\mathrm{f}}^{2} \cdot D \frac{1}{i^{2}}
$$

where $E_{\text {crf }}$ is the dynamic compressive modulus of elasticity in $\mathrm{MPa}, c_{1}$ is the correction coefficient, $L$ is the specimen length in $\mathrm{m}, f_{\mathrm{f}}$ is the natural frequency of flexural vibration in $\mathrm{kHz}, D$ is the material's bulk density in $\mathrm{kg} / \mathrm{m}^{3}$ and $i$ is the cross-sectional radius of gyration of a specimen in $\mathrm{m}$.
Each specimen was placed onto a soft pad and vibrated by a mechanical impulse produced by an impact hammer as seen in Figure 2. The natural frequencies of longitudinal $f_{\mathrm{L}}$, flexural $f_{\mathrm{f}}$ and torsional vibration $f_{\mathrm{t}}$ were determined by means of an oscilloscope with an acoustic emission (AE) sensor.

\subsubsection{Method for the static modulus of elasticity}

The principle of the test for determining the static modulus of elasticity is cyclic loading of a specimen while recording its longitudinal deformation. The specimen is first stressed with $0.5 \mathrm{MPa}$, after which the load is gradually increased to one third of the expected value of the compressive strength. The relative deformation at the corresponding stress is recorded and the modulus of elasticity is calculated with Equation (4):

$$
E_{\mathrm{c}}=\frac{\Delta \sigma}{\Delta \varepsilon}=\frac{\sigma_{\mathrm{a}}-\sigma_{\mathrm{b}}}{\varepsilon_{\mathrm{a}}-\varepsilon_{\mathrm{b}}}
$$

where $E_{\mathrm{c}}$ is the static compressive modulus of elasticity in $\mathrm{MPa}, \sigma_{\mathrm{a}}$ is the upper loading stress in $\mathrm{MPa}$, i.e., $1 / 3 \cdot f_{\mathrm{c}}$, $\sigma_{\mathrm{b}}$ is the basic loading stress in $\mathrm{MPa}$, i.e., $0.5 \mathrm{MPa}, \varepsilon_{\mathrm{a}}$ is the average deformation at the upper loading stress and $\varepsilon_{\mathrm{b}}$ is the average deformation at the basic loading stress.

In this experiment, the relative deformation was calculated from the deformations measured using mechanical strain gauges of $200 \mathrm{~mm}$ in length. Each specimen was always loaded with two preloading cycles and one reloading cycle, from which the value of the static modulus of elasticity was calculated using Equation (4). The expected 28- and 90-day compressive strengths of the specimens were determined from their cube compressive strength and from the measured dynamic properties. At the ages of $365 \mathrm{~d}$ and $730 \mathrm{~d}$, the expected beam compressive strength of the concrete was determined only from the measured values of the dynamic moduli of elasticity.

After the test of the static modulus of elasticity $E_{\mathrm{c}}$, the 28-day beam strength of one specimen was determined in order to verify the chosen upper loading stress $\sigma_{\mathrm{a}}$. The remaining specimens were left for the tests of the elastic moduli carried out at later ages. The same procedure was also performed at the ages of $90 \mathrm{~d}$ and 365 d. Thus, the static modulus of elasticity was per-

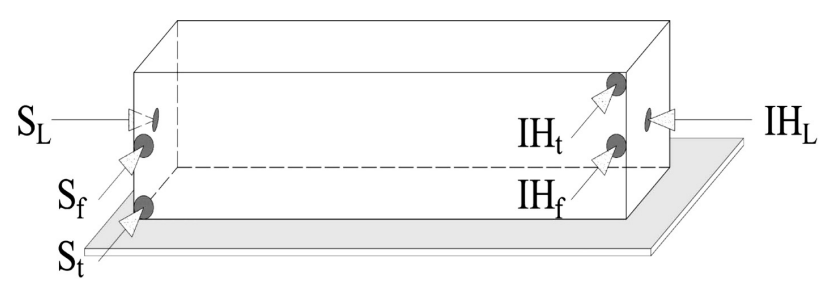

Figure 2: Diagram of the test arrangement for determining the resonance (natural) frequencies of a specimen; IH (impact hammer) indicates the place of the mechanical impulse, $\mathrm{S}$ is the position of the $\mathrm{AE}$ sensor, $L$ is the measurement of longitudinal vibration, $f$ is the measurement of flexural vibration and $t$ is the measurement of torsional vibration 


\section{KOCÁB et al.: EXPERIMENTAL ANALYSIS OF THE INFLUENCE OF CONCRETE ...}

formed repeatedly with some of the specimens at different ages. However, it must be noted that the test beam was always loaded only up to $1 / 3$ of its maximum compressive strength and thus $E_{\mathrm{c}}$ was only tested in terms of elastic deformations. The total maximum number of the loading cycles per specimen was 12 . This is a low number and with the multiple means of loading, it does not influence the final value of the static modulus of elasticity. ${ }^{16}$

\subsection{Material}

Four series of beam- and cube-shaped specimens were made for the experiment. The dimensions of the beams were $100 \times 100 \times 400 \mathrm{~mm}$ and the cubes were $150 \mathrm{~mm}$ in size. All the specimens were made from a concrete of the C 30/37 strength class taken from the agitator trucks present at the construction site of the bridge on Hradecká Street in Brno (Czech Republic). Table 1 lists the concretes used for making each series, their production dates and the parts of the bridge being built when the samples were taken.

Table 1: Specimens, type of concrete, production date

\begin{tabular}{|c|c|c|c|c|c|}
\hline Series & $\begin{array}{c}\text { Concrete } \\
\text { formula }\end{array}$ & $\begin{array}{c}\text { Concrete } \\
\text { ID }\end{array}$ & $\begin{array}{c}\text { Concrete } \\
\text { type }\end{array}$ & $\begin{array}{c}\text { Date of } \\
\text { casting }\end{array}$ & $\begin{array}{c}\text { Part of } \\
\text { bridge }\end{array}$ \\
\hline 1 & A & A & $\begin{array}{c}\text { air-en- } \\
\text { trained }\end{array}$ & $\begin{array}{c}17 \text { March } \\
2009\end{array}$ & abutment \\
\hline 2 & B & B & $\begin{array}{c}\text { air-en- } \\
\text { trained }\end{array}$ & $\begin{array}{c}1 \text { May } \\
2009\end{array}$ & $\begin{array}{c}\text { deck } \\
\text { beams }\end{array}$ \\
\hline 3 & C & C-1 & $\begin{array}{c}\text { not air-en- } \\
\text { trained }\end{array}$ & $\begin{array}{c}23 \text { May } \\
2009\end{array}$ & $\begin{array}{c}\text { deck slab } \\
\text { (span 1) }\end{array}$ \\
\hline 4 & C & C-2 & $\begin{array}{c}\text { not air-en- } \\
\text { trained }\end{array}$ & $\begin{array}{c}30 \text { May } \\
2009\end{array}$ & $\begin{array}{c}\text { deck slab } \\
\text { (span 2) }\end{array}$ \\
\hline
\end{tabular}

Table 2: Concrete compositions

\begin{tabular}{|c|c|c|c|}
\hline \multirow{2}{*}{ Component } & \multicolumn{3}{|c|}{$\mathrm{kg} / 1 \mathrm{~m}^{3}$ of FC } \\
\cline { 2 - 4 } & $\begin{array}{c}\text { Concrete } \\
\text { A }\end{array}$ & $\begin{array}{c}\text { Concrete } \\
\text { B }\end{array}$ & $\begin{array}{c}\text { Concrete } \\
\text { C }\end{array}$ \\
\hline $\begin{array}{c}\text { Cement CEM I 42.5 R } \\
\text { (Mokrá) }\end{array}$ & 400 & 400 & 400 \\
\hline Aggregate 0-4 mm (Ledce) & 700 & 700 & 700 \\
\hline $\begin{array}{c}\text { Aggregate 8-16 mm } \\
\text { (Olbramovice) }\end{array}$ & 669 & 669 & 669 \\
\hline $\begin{array}{c}\text { Aggregate 11-22 mm } \\
\text { (Lomnička) }\end{array}$ & 284 & 284 & 284 \\
\hline Water & 172 & 172 & 172 \\
\hline $\begin{array}{c}\text { Air-entraining admixture } \\
\text { (Sika Aer200) }\end{array}$ & 0.60 & 0.30 & - \\
\hline $\begin{array}{c}\text { Plasticiser (Sika ViscoCrete } \\
\text { 5-800 multimix) }\end{array}$ & 2.40 & 2.40 & 2.40 \\
\hline
\end{tabular}

The first series of the specimens was made during the construction of the bridge abutment. The second series was made during the casting of deck beams, the third specimen series was made when the deck slab of the bridge's span 1 was being cast and the fourth series of the specimens was made during the casting of the deck slab of span 2. Table 2 shows the composition of each concrete. Concrete A was taken from two agitator trucks; all the other concretes were sampled from three trucks. Fresh-concrete (FC) properties were always determined prior to the moulding of the specimens; their values are shown in Table 3.

Table 3: Fresh-concrete properties (the air content was not determined for concrete $\mathrm{C}$ as it was not air-entrained)

\begin{tabular}{|c|c|c|c|c|}
\hline Concrete & $\begin{array}{c}\text { Agitator } \\
\text { truck }\end{array}$ & $\begin{array}{c}\text { Slump test } \\
(\mathrm{mm})\end{array}$ & $\begin{array}{c}\text { Air content } \\
(\%)\end{array}$ & $\begin{array}{c}\text { Bulk density } \\
\left(\mathrm{kg} / \mathrm{m}^{3}\right)\end{array}$ \\
\hline \multirow{3}{*}{$\mathrm{A}$} & 1 & 130 & 4.5 & 2240 \\
\cline { 2 - 5 } & 2 & 120 & 4.2 & 2270 \\
\hline \multirow{4}{*}{$\mathrm{B}$} & 1 & 120 & 3.7 & 2290 \\
\cline { 2 - 5 } & 2 & 120 & 4.1 & 2280 \\
\cline { 2 - 5 } & 3 & 110 & 3.3 & 2320 \\
\hline \multirow{3}{*}{ C-1 } & 1 & 140 & - & 2330 \\
\cline { 2 - 5 } & 2 & 140 & - & 2320 \\
\hline \multirow{3}{*}{ C-2 } & 3 & 110 & - & 2340 \\
\cline { 2 - 5 } & 2 & 160 & - & 2330 \\
\cline { 2 - 5 } & 3 & 150 & - & 2340 \\
\hline
\end{tabular}

Table 4: Division of the test beams from individual agitator trucks (mixes) into test sets

\begin{tabular}{|c|c|c|c|c|c|c|c|}
\hline \multicolumn{2}{|c|}{ Concrete A } & \multicolumn{2}{c|}{ Concrete B } & \multicolumn{2}{c|}{ Concrete C-1 } & \multicolumn{2}{c|}{ Concrete C-2 } \\
\hline $\begin{array}{c}\text { Speci- } \\
\text { men }\end{array}$ & Mix & $\begin{array}{c}\text { Speci- } \\
\text { men }\end{array}$ & Mix & $\begin{array}{c}\text { Speci- } \\
\text { men }\end{array}$ & Mix & $\begin{array}{c}\text { Speci- } \\
\text { men }\end{array}$ & Mix \\
\hline A/N1 & 1 & B/N1 & 1 & C-1/N1 & 1 & C-2/N1 & 1 \\
\hline A/N2 & 1 & B/N2 & 2 & C-1/N2 & 2 & C-2/N2 & 2 \\
\hline A/N3 & 2 & B/N3 & 3 & C-1/N3 & 3 & C-2/N3 & 3 \\
\hline A/N4 & 1 & B/N4 & 1 & C-1/N4 & 1 & C-2/N4 & 1 \\
\hline A/N5 & 1 & B/N5 & 2 & C-1/N5 & 2 & C-2/N5 & 2 \\
\hline A/N6 & 2 & B/N6 & 3 & C-1/N6 & 3 & C-2/N6 & 2 \\
\hline A/S1 & 1 & B/S1 & 1 & C-1/S1 & 1 & C-2/S1 & 1 \\
\hline A/S2 & 1 & B/S2 & 2 & C-1/S2 & 2 & C-2/S2 & 2 \\
\hline A/S3 & 2 & B/S3 & 3 & C-1/S3 & 3 & C-2/S3 & 3 \\
\hline A/S4 & 1 & B/S4 & 1 & C-1/S4 & 1 & C-2/S4 & 1 \\
\hline A/S5 & 1 & B/S5 & 2 & C-1/S5 & 2 & C-2/S5 & 2 \\
\hline A/S6 & 2 & B/S6 & 3 & C-1/S6 & 3 & C-2/S6 & 2 \\
\hline
\end{tabular}

All the specimens from each construction day were placed onto a flat surface at the construction site, covered with moist geotextile, sprinkled with water and then covered with PE foil to prevent drying. After three days of curing, the current batch of the specimen was transported to the laboratory at the Institute of Building Testing at the BUT Faculty of Civil Engineering where they were demoulded. The beams of each series were then divided into two groups of six. The specimens from the first group were marked as N1-N6 and were immersed in water. The beam specimens from the second group were marked as S1-S6 and were stored in a normal laboratory environment with no additional water curing. The specimens with the $\mathrm{N}$ identification (stored in water at $20 \pm 3{ }^{\circ} \mathrm{C}$ ) represented the concrete that was being cured for the entire period. The specimens bearing the $\mathrm{S}$ identification (stored in normal laboratory conditions, at an ambient temperature of $20 \pm 3{ }^{\circ} \mathrm{C}$, a relative humidity of $50 \pm 10 \%$ ) represented the concrete, the curing of which 
D. KOCÁB et al.: EXPERIMENTAL ANALYSIS OF THE INFLUENCE OF CONCRETE ...

ended three days after it was cast. The assumption was that the way the specimens were stored at the construction site during the first three days was to simulate the concrete being thoroughly cured in the structure. The specimens made from the samples taken from each agitator truck were uniformly divided into individual sets (Table 4 ).

Apart from the beams, 150-mm cube specimens were also made for the purposes of determining the concretes' compressive strengths. Similarly to the beams, the cubes from each concrete were divided into two groups $-\mathrm{N}$ (cured under water) and $\mathrm{S}$ (uncured). The compressive strength was determined at the ages of $28 \mathrm{~d}$ and $90 \mathrm{~d}$; Table 5 shows the results.

Table 5: Cube compressive strength at the age of $28 \mathrm{~d}$ and $90 \mathrm{~d}$ in $\mathrm{MPa}$; each value represents the average of three specimens

\begin{tabular}{|c|c|c|c|c|c|}
\hline \multicolumn{2}{|c|}{ Age } & \multicolumn{2}{c|}{28 days } & \multicolumn{2}{c|}{90 days } \\
\hline \multirow{2}{*}{ Concrete } & Curing & $\begin{array}{c}\text { Average } \\
\text { value }\end{array}$ & $\begin{array}{c}\text { Sample's } \\
\text { standard } \\
\text { deviation }\end{array}$ & $\begin{array}{c}\text { Average } \\
\text { value }\end{array}$ & $\begin{array}{c}\text { Sample's } \\
\text { standard } \\
\text { deviation }\end{array}$ \\
\hline \multirow{2}{*}{$\mathrm{A}$} & $\mathrm{N}$ & 41.0 & 0.57 & 45.6 & 0.25 \\
\cline { 2 - 6 } & $\mathrm{S}$ & 41.5 & 2.06 & 41.2 & 2.55 \\
\hline \multirow{2}{*}{$\mathrm{B}$} & $\mathrm{N}$ & 46.4 & 3.12 & 48.1 & 8.70 \\
\cline { 2 - 6 } $\mathrm{C}-1$ & $\mathrm{~S}$ & 50.3 & 1.68 & 52.0 & 4.16 \\
\hline \multirow{2}{*}{$\mathrm{C}-2$} & $\mathrm{~N}$ & 51.7 & 3.44 & 60.5 & 1.56 \\
\cline { 2 - 6 } & $\mathrm{S}$ & 52.4 & 1.55 & 57.7 & 2.19 \\
\cline { 2 - 6 } & $\mathrm{N}$ & 49.2 & 3.80 & 58.1 & 1.26 \\
\hline
\end{tabular}

The dynamic modulus of elasticity of the beams in every series was determined by means of the ultrasonic-pulse velocity test $\left(E_{\mathrm{cu}}\right)$ as well as the resonance test $\left(E_{\mathrm{rcL}}\right.$ from the natural frequency of the longitudinal vibration and $E_{\text {rcf }}$ from the natural frequency of the flexural vibration) at the ages of $(3,7,28,90,365$ and 730) $\mathrm{d}$. The beams were also tested for the value of their static compressive modulus of elasticity $E_{\mathrm{c}}$ at the ages of (28, 90, 365 and 730) d.

\section{RESULTS AND DISCUSSION}

The dynamic modulus of elasticity of the 3-day-old concrete of all the series was tested after demoulding, i.e., before placing specimens N1-N6 in water and before placing specimens S1-S6 under laboratory conditions with no contact with liquid water. For this reason, the values of both sets ( $\mathrm{N}$ and $\mathrm{S}$ ) of all the series are almost identical. However, four days later, i.e., at the age of $7 \mathrm{~d}$, a positive influence of curing the concrete under water is clearly visible. The dynamic modulus of elasticity for the cured sets $\mathrm{N}$ increased more rapidly compared to the uncured sets $\mathrm{S}$. The concretes stored in laboratory conditions were not protected against drying in any way. In fact, massive water evaporation was permitted by the design. A drop in the relative humidity in the concrete pore structure influences cement hydration $^{30}$ and simultaneously affects the mechanical
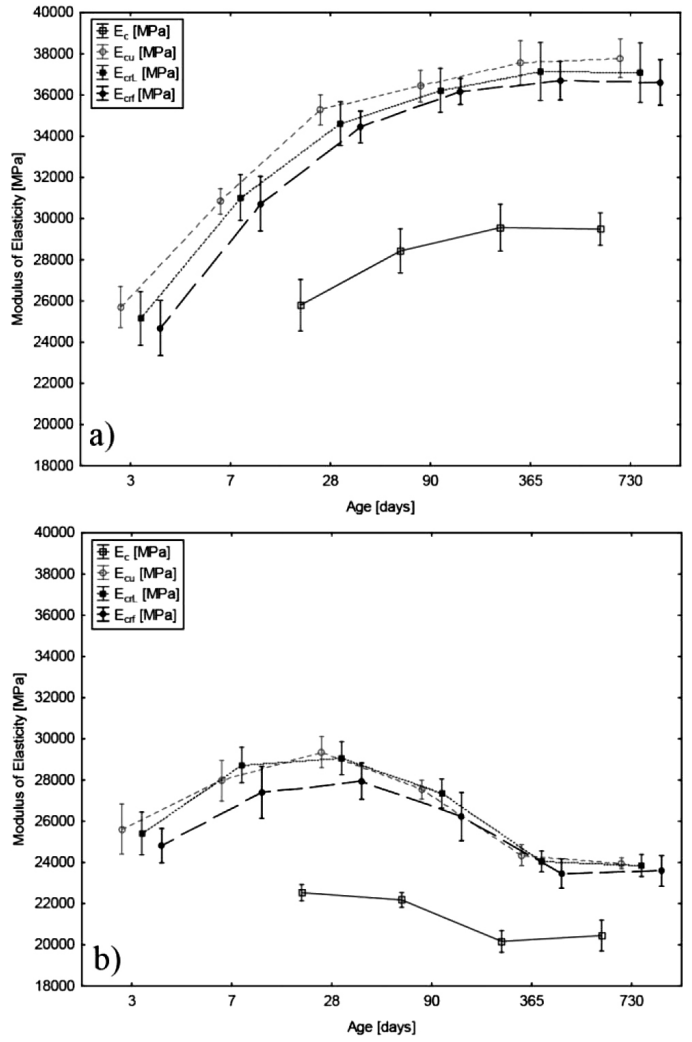

Figure 3: Diagram of the progress of the average values of elastic moduli for concrete A; the error bars indicate sample standard deviations; a) set of cured specimens $\mathrm{N}$; b) set of uncured specimens $\mathrm{S}$
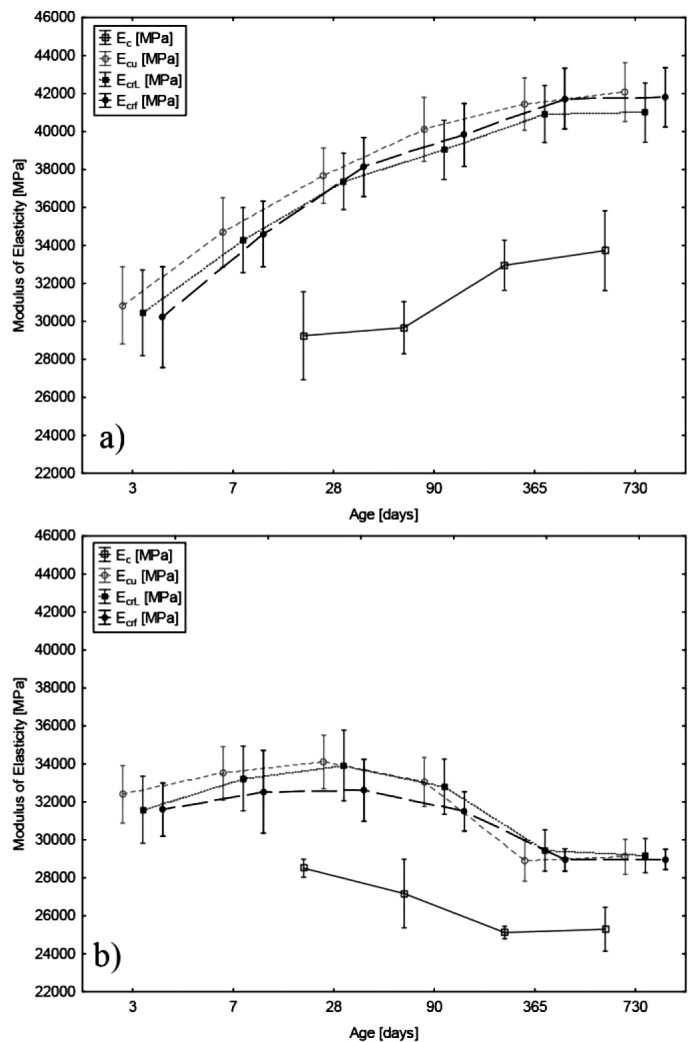

Figure 4: Diagram of the progress of the average values of elastic moduli for concrete B; the error bars indicate sample standard deviations; a) set of cured specimens $\mathrm{N}$; b) set of uncured specimens $\mathrm{S}$ 


\section{KOCÁB et al.: EXPERIMENTAL ANALYSIS OF THE INFLUENCE OF CONCRETE ...}

properties of the concrete body. ${ }^{20}$ This explains different increases in the dynamic elastic moduli of the cured and uncured concretes. The trend is clearly visible on all the concretes before the age of $28 \mathrm{~d}$. The concrete stored in water saw a substantially steeper increase in the observed dynamic properties as opposed to the concrete stored in the air; Figures 3-6.

Apart from the dynamic moduli of elasticity $E_{\mathrm{cu}}, E_{\mathrm{crL}}$ and $E_{\text {crf }}$, the static modulus of elasticity $E_{\mathrm{c}}$ was also determined at the age of $28 \mathrm{~d}$. The cured concrete of all the series reached higher values of the static modulus of elasticity than the uncured concrete. However, the differences between the average values of 28-day elastic moduli of the individual test sets are not particularly significant. The influence of curing was of the greatest magnitude for the air-entrained concrete A, where the difference between the values of the static elastic modulus of the cured and uncured concrete was $12.8 \%$; Table 6. The data was compared and the conclusions were drawn using an analysis of variance (ANOVA) at a significance level of 0.05 .

There is a very interesting difference in the behaviour of the cured and uncured concretes at the age of $28 \mathrm{~d}$ and $90 \mathrm{~d}$. While the concrete stored under water still shows an increase in the dynamic and static modulus of elasticity, the case of the uncured concrete is different. The average 28-day values of both the static and dynamic modulus of elasticity of the uncured concrete begin to
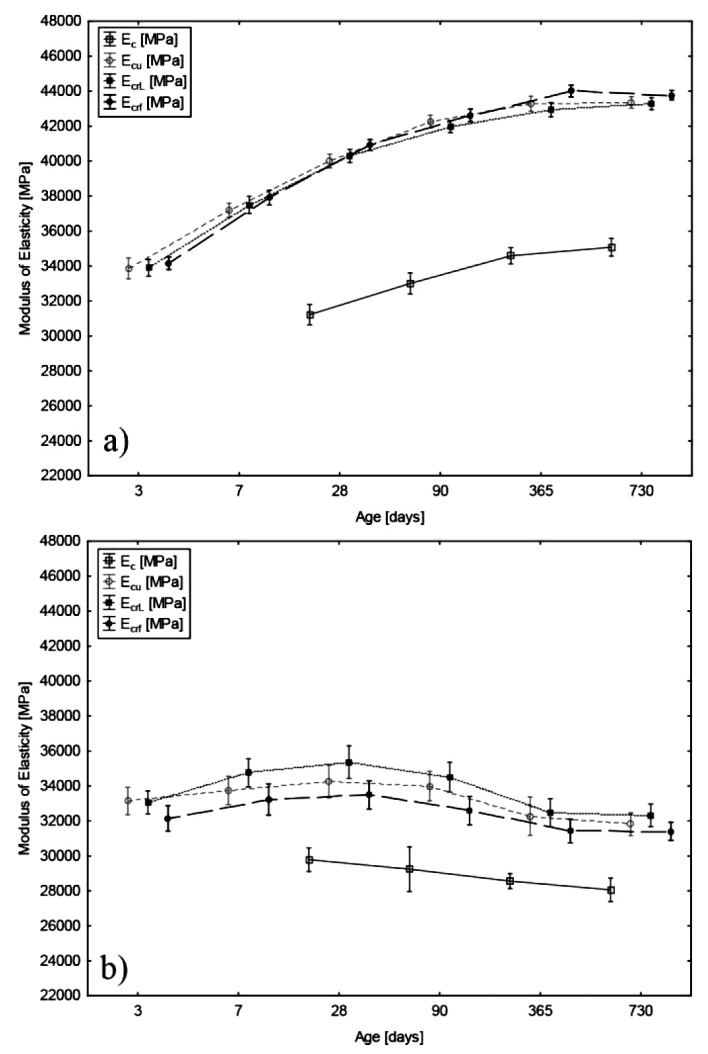

Figure 5: Diagram of the progress of the average values of elastic moduli for concrete $\mathrm{C}-1$; the error bars indicate sample standard deviations; a) set of cured specimens $\mathrm{N}$; b) set of uncured specimens $\mathrm{S}$ stagnate and subsequently even decrease. At the age of $90 \mathrm{~d}$, the dynamic values of the uncured concrete $\mathrm{S}$ dropped approximately to the values of the 7-day uncured concrete of all the series. Comparing the results of the 90-day dynamic elastic moduli of uncured concrete $\mathrm{S}$ with the results for cured concrete $\mathrm{N}$ at the age of $7 \mathrm{~d}$, the values of concrete $\mathrm{S}$ are lower for all the series (Table 6).

The fact that the uncured concrete $\mathrm{S}$ saw no continuous increase in the observed properties (in comparison with cured concrete N) can be explained with the lack of water necessary for the cement to fully hydrate. ${ }^{20,30}$ The rapid water evaporation from the surface of the concrete specimens affects the progress and the magnitude of concrete shrinkage. The stress created as a result of volume changes in the concrete at its early age can lead to the appearance of microscopic defects in the internal structure of the concrete, which further affects the development of its mechanical properties. A similar stagnation in the material properties of the uncured concrete compared with a cured one was also published by the authors of papers ${ }^{24,25}$, where the parameter observed was the compressive strength. Insufficient concrete curing was also reflected in the final values of the elastic modulus at the later ages of the concrete.

The dynamic moduli of elasticity of uncured concrete $\mathrm{S}$ at the ages of $365 \mathrm{~d}$ and $730 \mathrm{~d}$ reach lower values than those determined for the same concrete at the age $3 \mathrm{~d}$
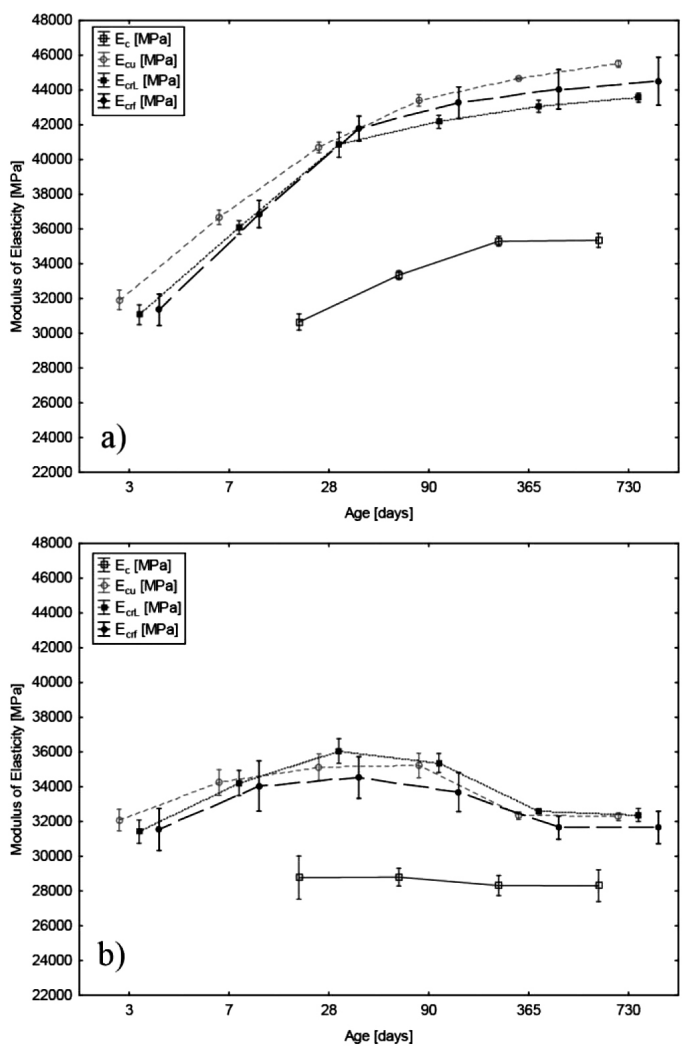

Figure 6: Diagram of the progress of the average values of elastic moduli for concrete C-2; the error bars indicate sample standard deviations; a) set of cured specimens $\mathrm{N}$; b) set of uncured specimens $\mathrm{S}$ 
D. KOCÁB et al.: EXPERIMENTAL ANALYSIS OF THE INFLUENCE OF CONCRETE ...

Table 6: Average values of the static modulus of elasticity $E_{\mathrm{c}}$ and the dynamic modulus of elasticity $E_{\mathrm{cu}}$ determined by means of the ultrasonic-pulse velocity test; at the ages of $28 \mathrm{~d}$ and $730 \mathrm{~d}$, a percentage difference between the elastic moduli of the cured and uncured concrete is calculated

\begin{tabular}{|c|c|c|c|c|c|c|c|c|c|c|}
\hline \multirow{2}{*}{ Concrete } & \multirow{2}{*}{$\begin{array}{l}\text { Type of } \\
\text { elastic } \\
\text { modulus }\end{array}$} & \multirow{2}{*}{ Set } & \multicolumn{6}{|c|}{ Age (days) } & \multirow{2}{*}{$\begin{array}{l}\text { Difference at } \\
\text { the age of } \\
28 \mathrm{~d}(\%)\end{array}$} & \multirow{2}{*}{$\begin{array}{l}\text { Difference at } \\
\text { the age of } \\
730 \mathrm{~d}(\%)\end{array}$} \\
\hline & & & 3 & 7 & 28 & 90 & 365 & 730 & & \\
\hline \multirow{4}{*}{ A } & \multirow{2}{*}{$E_{\mathrm{c}}$} & $\mathrm{N}$ & - & - & 25800 & 28400 & 29600 & 29500 & \multirow{2}{*}{12.8} & \multirow{2}{*}{30.5} \\
\hline & & $S$ & - & - & 22500 & 22200 & 20200 & 20500 & & \\
\hline & \multirow{2}{*}{$E_{\mathrm{cu}}$} & $\mathrm{N}$ & 25700 & 30800 & 35300 & 36400 & 37600 & 37800 & \multirow{2}{*}{16.7} & \multirow{2}{*}{36.5} \\
\hline & & $\mathrm{S}$ & 25600 & 28000 & 29400 & 27500 & 24400 & 24000 & & \\
\hline \multirow{4}{*}{ B } & \multirow{2}{*}{$\mathrm{E}_{\mathrm{c}}$} & $\mathrm{N}$ & - & - & 29200 & 29700 & 33000 & 33700 & \multirow{2}{*}{2.4} & \multirow{2}{*}{24.9} \\
\hline & & $S$ & - & - & 28500 & 27200 & 25100 & 25300 & & \\
\hline & \multirow{2}{*}{$E_{\mathrm{cu}}$} & $\mathrm{N}$ & 30800 & 34700 & 37700 & 40100 & 41400 & 42100 & \multirow{2}{*}{9.5} & \multirow{2}{*}{30.9} \\
\hline & & $S$ & 32400 & 33500 & 34100 & 33000 & 28900 & 29100 & & \\
\hline \multirow{4}{*}{ C-1 } & \multirow{2}{*}{$\mathrm{E}_{\mathrm{c}}$} & $\mathrm{N}$ & - & - & 31200 & 33000 & 34600 & 35100 & \multirow{2}{*}{4.5} & \multirow{2}{*}{19.9} \\
\hline & & $\mathrm{S}$ & - & - & 29800 & 29200 & 28600 & 28100 & & \\
\hline & \multirow{2}{*}{$E_{\mathrm{cu}}$} & $\mathrm{N}$ & 33900 & 37200 & 40000 & 42300 & 43300 & 43400 & \multirow{2}{*}{14.3} & \multirow{2}{*}{26.7} \\
\hline & & $S$ & 33100 & 33800 & 34300 & 34000 & 32300 & 31800 & & \\
\hline \multirow{4}{*}{$\mathrm{C}-2$} & \multirow{2}{*}{$\mathrm{E}_{\mathrm{c}}$} & $\mathrm{N}$ & - & - & 30600 & 33300 & 35300 & 35300 & \multirow{2}{*}{5.9} & \multirow{2}{*}{19.8} \\
\hline & & $\mathrm{S}$ & - & - & 28800 & 28800 & 28300 & 28300 & & \\
\hline & \multirow{2}{*}{$E_{\mathrm{cu}}$} & $\mathrm{N}$ & 31900 & 36700 & 40700 & 43400 & 44700 & 45500 & \multirow{2}{*}{13.8} & \multirow{2}{*}{29.0} \\
\hline & & $S$ & 32100 & 34200 & 35100 & 35200 & 32300 & 32300 & & \\
\hline
\end{tabular}

(Table 6). The only exception is concrete C-2, for which these values are at the same level. The reason for this decrease is probably a change in the internal structure of the concrete manifesting itself as micro-defects. It was found that concrete drying causes its shrinkage, due to which microcracks and microscopic defects form in its internal structure. ${ }^{31}$ These microcracks further change the mechanical properties of the concrete and damage its quality, modulus of elasticity and durability. ${ }^{31-33}$

The issue of removing concrete from direct contact with liquid water and the magnitude of shrinkage caused by doing this are documented in references ${ }^{22,23,31,34}$. The difference in the behaviour of the cured and uncured concrete is better and more conclusively reflected in the results of dynamic tests, which react to damage to the internal structure with a much greater sensitivity than static

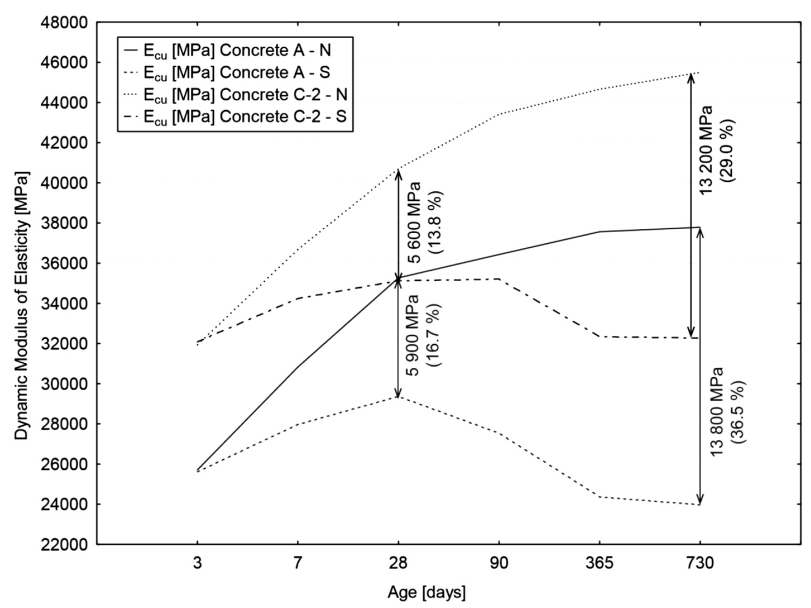

Figure 7: Diagram showing the influence of concrete curing on its dynamic modulus of elasticity $E_{\mathrm{cu}}$ including the difference between the resulting values compressive tests. Table 6 shows the differences between the average values of both static and dynamic moduli of elasticity; it shows the difference, in percent, between the elastic moduli of cured concrete $\mathrm{N}$ and uncured concrete $\mathrm{S}$ at the ages of $28 \mathrm{~d}$ and $730 \mathrm{~d}$.

The dynamic elastic moduli determined by means of the ultrasonic-pulse velocity test $\left(E_{\mathrm{cu}}\right)$ showed results similar to those obtained with the resonance method ( $E_{\mathrm{crL}}$ and $E_{\mathrm{crf}}$ ); (Figures 3-6). Thus, the modulus of elasticity measured with the ultrasonic-pulse velocity test $\left(E_{\mathrm{cu}}\right)$ was chosen to represent the dynamic elastic moduli for the overall evaluation of the behaviour of cured and uncured concretes as shown in Table 6. Figure 7 displays a diagram constructed from the data. For the sake of clarity, the diagram includes only two series of specimens the air-entrained concrete of series 1 (concrete A) and the non-air-entrained concrete of series 4 (concrete C-2).

Concerning the air-entrained concretes $\mathrm{A}$ and $\mathrm{B}$, the differences between the 730-day dynamic moduli of elasticity Ecu for the cured and uncured concretes are $36.5 \%$ and $30.9 \%$. The differences between the static moduli of elasticity $E_{\mathrm{c}}$ are $30.5 \%$ and $24.9 \%$. The nonair-entrained concrete $\mathrm{C}$ again shows a greater difference in the dynamic modulus of elasticity at the age of $730 \mathrm{~d}$ (26.7\% and $29.0 \%$ ), compared with the static modulus of elasticity (19.9 and $19.8 \%$ ). In summary, the air-entrained concretes saw a greater decrease in the observed parameters.

\section{CONCLUSIONS}

The experiment results show a positive influence, which the curing method has on the concrete's resulting modulus of elasticity. The concrete cured under water 


\section{KOCÁB et al.: EXPERIMENTAL ANALYSIS OF THE INFLUENCE OF CONCRETE ...}

sees an increase in the value of both dynamic and static modulus of elasticity over time. This trend continues at much later ages as well (an age of $90 \mathrm{~d}$ or more). On the other hand, the modulus of elasticity of the uncured concrete exposed to air demonstrably increases only during the first $28 \mathrm{~d}$ and reaches lower values than the concrete that was water cured. Between the ages of $28 \mathrm{~d}$ and $90 \mathrm{~d}$, the dynamic modulus of elasticity of the uncured concrete stagnates and begins to decrease. It was found that the value of the static modulus of elasticity of the uncured concrete determined at the age of $730 \mathrm{~d}$ was lower than the value measured at the age of $28 \mathrm{~d}$. In fact, the 730 -day value of the dynamic modulus of elasticity of the uncured concrete was lower than the value measured at the age of $3 \mathrm{~d}$. The decrease in the properties of the uncured concrete was significant. All the series of the tested concretes exhibited a similar trend in the development of the values of the elastic modulus over time for the cured as well as uncured concrete.

\section{Acknowledgement}

This paper has been worked under the project No. LO1408 "AdMaS UP - Advanced Materials, Structures and Technologies", supported by the Ministry of Education, Youth and Sports under the "National Sustainability Programme I".

\section{REFERENCES}

${ }^{1}$ H. S. Abdelgader, A. S. Elbaden, A. Diouri, N. Khachani, M. A. Talbi, Concreting method that produce high modulus of elasticity, MATEC Web of Conferences, (2014) 11, doi:10.1051/matecconf/ 20141103012

${ }^{2}$ C. H. Tsai, D. S. Hsu, Diagnosis of Reinforced Concrete Structural Damage Base on Displacement Time History Using the Back-Propagation Neural Network Technique, Journal of Computing in Civil Engineering, 16 (2002) 1, 49-58, doi:10.1061/(ASCE)08873801(2002)16:1(49)

${ }^{3}$ T. Komarkova, M. Kralikova, P. Kovacs, Application of computed tomography in comparison with the standardized methods for determining the permeability of cement-composite structures, Mater. Tehnol., 49 (2015) 4, 587-595, doi:10.17222/mit.2014.194

${ }^{4}$ L. Pazdera, L. Topolar, J. Smutny, K. Timcakova, Nondestructive Testing of Advanced Concrete Structure during Lifetime, Advances in Materials Science and Engineering, 1-5 (2015), doi:10.1155/2015/286469

${ }^{5}$ H. Yildirım, O. Sengul, Modulus of elasticity of substandard and normal concretes, Construction and Building Materials, 25 (2011) 4, 1645-1652, doi:10.1016/j.conbuildmat.2010.10.009

${ }^{6}$ B. Lee, S. H. Kee, T. Oh, Y. Y. Kim, Effect of Cylinder Size on the Modulus of Elasticity and Compressive Strength of Concrete from Static and Dynamic Tests, Advances in Materials Science and Engineering, 1-12 (2015), doi:10.1155/2015/580638

R. V. Silva, R. Vasco, J. De Brito, R. K. Dhir, Establishing a relationship between modulus of elasticity and compressive strength of recycled aggregate concrete, Journal of Cleaner Production, 112 (2016), 2171-2186, doi:10.1016/j.jclepro.2015.10.064.

${ }^{8}$ M. Zhang, A. P. Jivkov, Micromechanical modelling of deformation and fracture of hydrating cement paste using X-ray computed tomography characterisation, Composites Part B: Engineering, 88 (2016), 64-72, doi:10.1016/j.compositesb.2015.11.007
${ }^{9}$ Y. Zhou, J. Gao, Z. Sun, W. Qu, A fundamental study on compressive strength, static and dynamic elastic moduli of young concrete, Construction and Building Materials, 98 (2015), 137-145, doi:10.1016/j.conbuildmat.2015.08.110

${ }^{10}$ J. S. Park, Y. Kim, J. R. Cho, S. J. Jeon, Early-Age Strength of U1tra-High Performance Concrete in Various Curing Conditions, Materials, 8 (2015) 8, 5537-5553, doi:10.3390/ma8085261

${ }^{11}$ M. Dehestani, I. M. Nikbin, S. Asadollahi, Effects of specimen shape and size on the compressive strength of self-consolidating concrete (SCC), Construction and Building Materials, 66 (2014), 685-691, doi: 10.1016/j.conbuildmat.2014.06.008

${ }^{12}$ C. K. Ma, A. Awang, W. Omar, Flexural ductility design of confined high-strength concrete columns: Theoretical modelling, Measurement, 78 (2016), 42-48, doi:10.1016/j.measurement.2015.09.039

${ }^{13}$ M. Nematzadeh, M. Naghipour, Compressive strength and modulus of elasticity of freshly compressed concrete, Construction and Building Materials, 34 (2012), 476-485, doi:10.1016/j.conbuildmat. 2012.02.055

${ }^{14}$ EN 1992-1-1, Eurocode 2: Design of concrete structures - Part 1-1: General rules and rules for buildings, 1 Brussels, Belgium: Comité Européen de Normalisation (CEN), 2008

${ }^{15}$ M. Shariq, J. Prasad, H. Abbas, Effect of GGBFS on age dependent static modulus of elasticity of concrete, Construction and Building Materials, 41 (2013), 411-418, doi:10.1016/j.conbuildmat.2012. 12.035

${ }^{16}$ A. Neville, J. Brooks, Concrete technology, 2nd ed., Harlow, England, Prentice Hall, 2010

${ }^{17}$ J. Newman, B. S. Choo, Advanced concrete technology: Concrete properties, 1st edition, Amsterdam, Elsevier, 2003

${ }^{18}$ A. Neville, Properties of concrete, 5th ed., New York, Pearson, 2011

${ }^{19}$ N. Kockal, Validity and reliability of estimated modulus of elasticity of cementitious materials, IOP Conference Series: Materials Science and Engineering, 103 (2015), doi:10.1088/1757-899X/103/1/012024

${ }^{20}$ B. Liu, W. Lv, L. Li, P Li, Effect of moisture content on static compressive elasticity modulus of concrete, Construction and Building Materials, 69 (2014), 133-142, doi:10.1016/j.conbuildmat.2014. 06.094

${ }^{21}$ S. N. Shoukry, G. W. William, B. Downie, M. Y. Riad, Effect of moisture and temperature on the mechanical properties of concrete, Construction and Building Materials, 25 (2011) 2, 688-696, doi:10.1016/j.conbuildmat.2010.07.020

${ }^{22}$ M. Maslehuddin, M. Ibrahim, M. Shameem, M. R. Ali, M. H. Al-Mehthel, Effect of curing methods on shrinkage and corrosion resistance of concrete, Construction and Building Materials, 41 (2013), 634-641, doi:10.1016/j.conbuildmat.2012.12.064

${ }^{23}$ A. S. Al-Gahtani, Effect of curing methods on the properties of plain and blended cement concretes, Construction and Building Materials, 24 (2010) 3, 308-314, doi:10.1016/j.conbuildmat.2009.08.036

${ }^{24}$ M. Uddin, M. Jameel, H. Sobuz, M. Islam, N. Hasan, Experimental study on strength gaining characteristics of concrete using Portland Composite Cement, KSCE Journal of Civil Engineering, 17 (2013) 4, 789-796, doi:10.1007/s12205-013-0236-X

${ }^{25}$ B. Ozer, M. H. Ozkul, The influence of initial water curing on the strength development of ordinary portland and pozzolanic cement concretes, Cement and Concrete Research, 34 (2004) 1, 13-18, doi:10.1016/S0008-8846(03)00185-6

${ }^{26}$ X. Lu, Q. Sun, W. Feng, J. Tian, Evaluation of dynamic modulus of elasticity of concrete using impact-echo method, Construction and Building Materials, 47 (2013), 231-239, doi:10.1016/j.conbuildmat. 2013.04.043

${ }^{27}$ H. Simonova, I. Havlikova, P. Danek, The effect of a superplasticizer admixture on the mechanical fracture parameters of concrete, Mater. Tehnol., 49 (2015) 3, 417-421, doi:10.17222/mit.2014.114

${ }^{28}$ T. Holusova, S. Seitl, A. Fernández-Canteli, Numerical Simulation of Modified Compact Tension Test Depicting of Experimental Measurement by ARAMIS, Key Engineering Materials, 627 (2014), 277-280, doi:10.4028/www.scientific.net/KEM.627.277 


\section{MATERIALI IN TEHNOLOGIJE/MATERIALS AND TECHNOLOGY (1967-2017) - 50 LET/50 YEARS}

\section{KOCÁB et al.: EXPERIMENTAL ANALYSIS OF THE INFLUENCE OF CONCRETE ...}

${ }^{29}$ İ. B. Topçu, Alternative estimation of the modulus of elasticity for dam concrete, Cement and Concrete Research, 35 (2005) 11 2199-2202, doi:10.1016/j.cemconres.2004.08.010

${ }^{30}$ J. Newman, J. B. Choo, Advanced concrete technology: Concrete properties, 1st edition, Amsterdam: Elsevier, 2003

${ }^{31}$ Y. Wei, W. Guo, X. Zheng, Integrated shrinkage, relative humidity, strength development, and cracking potential of internally cured concrete exposed to different drying conditions, Drying Technology, 34 (2015) 7, 741-752, doi:10.1080/07373937.2015.1072549
${ }^{32}$ G. De Schutter, Hydration and temperature development of concrete made with blast-furnace slag cement, Cement and Concrete Research, 29 (1999) 1, 143-149, doi:10.1016/S0008-8846(98)00229-4

${ }^{33}$ G. De Schutter, L. Taerwe, General hydration model for portland cement and blast furnace slag cement, Cement and Concrete Research, 25 (1995) 3, 593-604, doi:10.1016/0008-8846(95)00048-H

${ }^{34}$ S. H. Alsayed, M. A. Amjad, Effect of curing conditions on strength, porosity, absorptivity, and shrinkage of concrete in hot and dry climate, Cement and Concrete Research, 24 (1994) 7, 1390-1398, doi:10.1016/0008-8846(94)90124-4 